\title{
Branding Agama dalam Membentuk Identitas Politik: Kajian Mengenai Selebriti Islam pada Aksi 212
}

\author{
Revta Fariszy \\ Vegasari Adya
}

| Program Studi Ilmu Komunikasi UPN Veteran Yogyakarta Bisa dihubungi melalui email revtafariszy@upnyk.ac.id

| Program Studi Tata Kelola Seni, Fakultas Seni Rupa, Institut Seni Indonesia, Yogyakarta. Bisa dihubungi melalui email vegasari.adya@isi.ac.id

\begin{abstract}
ABSTRAK
The 212 Rally has many other interest outside the religious context. The rally strengthens the identity of Muslims and indicating that the hegemony of religious is able to contribute to the world of politics. Unlike usual, 212 Rally presents actors whose are not only from politicians or religious circles, but also public figures from the entertainment industry. However, the participation of public figures is full of political interests, because some of them are incorporated with certain political parties. This paper analyzes the construction of the religious identity of public figures and their relation to politics. Referring to the theory and concept of political identity and personal branding, there are indications that public figures construct their religious identity for political purposes and agendas.
\end{abstract}

Keyword: political identity, self-presentation, personal branding.

\section{Pendahuluan}

Belum lekang di ingatan kita tentang Aksi 212 yang merenggut perhatian rakyat Indonesia saat itu. Tanggal 2 Desember 2016, dipimpin oleh Imam Besar Front Pembela Islam (FPI), Rizieq Shihab, masyarakat muslim memenuhi sekat-sekat utama di Ibukota Jakarta dengan seruan takbir dan sholawat. Aksi tersebut merupakan bentuk protes terhadap kasus dugaan penistaan Kitab Al-Quran yang dilakukan oleh Gubernur DKI Jakarta saat itu, Basuki Tjahaja Purnama. Aksi yang juga disebut Aksi Bela Islam ini adalah rangkaian ketiga dari dua aksi bertujuan sama yang dilakukan pada 4 November 2016 (Aksi 411) dan 15 November 2018. Apa yang dituntut massa aksi pun terpenuhi dengan dijatuhkannya vonis bersalah kepada Basuki Tjahaya Purnama pada 9 Mei 2017 (CNN
Indonesia 2018). Melihat proses keberlangsungannya, aksi ini menunjukkan bagaimana agama memiliki kekuatan dan andil yang besar dalam dunia pemerintahan dan politik dilndonesia.

Irisan antara agama dengan politik sangat kental terasa pada peristiwa 2 Desember 2016 ini. Aksi 212 ini merupakan akar gerakan Islam politik yang berujung pada Pemilihan Presiden (Pilpres) tahun 2019. Hal ini ditandai oleh tokoh-tokoh politik dari partai Gerindra dan Partai Keadilan Sejahtera yang berpartisipasi dala, Aksi 212. Di antaranya Prabowo Subianto, Anies Baswedan, Fadli Zon dan Zulkifli Hasan, yang merupakan tokoh-tokoh politik yang condong pada kubu Calon Presiden 
Prabowo Subianto dan Calon Wakil Presiden Sandiaga Uno dalam Pilpres 2019 (Afriyan, 2018). Tak hanya itu, Rizieq Shihab sebagai Imam Besar FPI pun telah menyatakan dukungannya pada kubu calon presiden Prabowo Subianto dan menyerukan kepada peserta Aksi 212 untuk mengikuti alur dukungannya (Siddiq, 2018). Secara tidak langsung, aksi ini menjadi pembuka aliran suara Pilpres tahun 2019.

Selain singgungan dengan Pilpres 2019, Aksi 212 ini juga mengandung bahasan tentang identitas. Identitas yang direpresentasikan pada aksi ini adalah dalam bentuk kelompok dan personal. Secara kelompok, aksi ini merupakan jalan pembentukan kelompok penyebaran Islam yang baru. Secara individu pun tidak kalah menarik, selain pengukuhan dan penguatan identitas politik dari tokoh politik dan tokoh agama, beberapa selebriti atau figur publik pun turut hadir dalam aksi damai 212. Keikutsertaan ini tidak dapat dipandang secara sebelah mata, karena figur publik memiliki citra personal yang dilihat langsung oleh masyarakat, serta dianggap sebagai sosok percontohan.

Tidak sedikit figur publik nasional yang berpartisipasi pada Aksi 212 menjadi hal yang menarik. Beberapa di antaranya adalah selebriti Teuku Wisnu, Irfan Hakim, Irwansyah, Fauzi Baadilla dan Ahmad Dhani. Namun selebritiselebriti tersebut tergolong baru mendalami agama Islam, atau populer dengan sebutan hijrah. Dalam 5 tahun terakhir ini, hijrah menjadi tren yang mulai merambah di kalangan para selebriti. Diantaranya adalah Teuku Wisnu, Irwansyah, Ari Untung, Dimas Seto, Dewi Sandra, Alyssa
Subandono dan Shireen Sungkar. Selebritiselebriti tersebut kian mendalami agama Islam hingga kerap mengikuti beberapa kelompok kajian (Aragon, 2018).

Di sisi lain, tokoh selebriti yang kemudian terjun ke dunia perpolitikan belakangan telah menjadi hal yang lumrah. Di lingkup internasional misalnya ada Steven Seagal, Arnold Schwarzenegger dan Ronald Reagan yang telah membintang beberapa film layar lebar sebelum dirinya terpilih sebagai presiden Amerika Serikat (Larasati, 2018). Di Indonesia, berubahnya sistem pemilihan umum menjadi proporsional terbuka sejak pemilu 2004 (Darmawan, 2015), membuat masyarakat umum, termasuk selebriti, dapat mencalonkan diri dalam legislatif. Beberapa selebriti senior seperti Adjie Massaid, Rano Karno, Desy Ratnasari, Eko Patrio, Dede Yusuf dan Dedi Mizwar merupakan contoh selebriti yang sukses menggeluti dunia politik dan menduduki beberapa jabatan di daerah. Selebriti muda pun tak kalah saing, sebut saja Rachel Maryam, Mulan Jameela dan Tommy Kurniawan. Stabilnya jumlah selebriti yang terjun ke dunia politik menunjukkan bahwa fenomena ini bukanlah tren semata.

Fakta terpilihnya sejumlah selebriti dalam kancah legislatif menunjukkan adanya kecenderungan masyarakat untuk memilih selebriti. Dari data tiga pemilihan legislatif terakhir, angka selebriti yang terpilih stabil di angka belasan (Dewan Pers, 2009; Gerintya, 2018; Farisa, 2019). Terpilihnya selebriti menurut Adi Prayitno merupakan hal yang wajar mengingat dalam kampanye, selebriti diuntungkan dengan popularitas yang dimilikinya (dalam Hastanto, 2020). 
Fenomena keterlibatan selebriti dalam ajang keagamaan dan politik memiliki imbas yang besar pada khalayak umum. Menganalisis fenomena ini secara lebih kritis, terdapat kecenderungan penggunaan identitas agama yang dilakukan oleh selebriti sebagai pendekatan politik. Fauzi Baadila dan Rachel Maryam misalnya, selain membentuk identitas Islam, mereka juga aktif masuk dalam keanggotaan partai politik. Bila mengacu pada data yang dikemukakan Altman (2005), koverasi selebriti pada media massa semakin meningkat setiap tahunnya. Kekuatan khalayak tentu dapat dijadikan sebagai nilai tambah dalam keterlibatan selebriti dalam ranah politik. Penelitian ini akan membahas fenomena selebriti dalam membentuk citra agamis dengan mengikuti Aksi 212 dengan mendekatkannya dengan wacana pembentukan identitas melalui media sosial.

\section{Kerangka Pemikiran}

\section{Kajian Selebriti}

Selebriti menjadi salah satu yang menarik untuk dikaji mengingat budaya dan kehidupan keselebritisan berbeda dengan masyarakat pada umumnya. Selebriti bila menurut Boorstin adalah orang yang "dikenal karena keterkenalannya" (Turner, 2014). Keterkenalan tersebut biasanya didapatkan karena industri hiburan, keselebritian ataupun olahraga, seperti menjadi atlet yang sukses (Turner, 2014). Selebriti dalam dunia hiburan biasanya merupakan konstrusi dalam media dengan tujuan untuk memenuhi harapan terhadap sebuah kehidupan (Boorstin dalam Turner, 2014). Oleh karenanya, kehidupan yang dibuat dalam media, baik kehidupan dalam serial drama ataupun reality show, merupakan kehidupan idaman masyarakat mayoritas.

Kepopuleran dan keterkenalan selebriti tidak jauh dari peran media. Pesan dalam media secara tidak langsung mengostruksi khalayak dan mempengaruhi masyarakat secara kultural (Rojek, 2013). Di media cetak, beberapa kolom seperti wawancara, profil atau cara pandang selebriti terhadap sesuatu biasanya terdapat dalam tabloid atau majalah (Turner, 2014). Sedangkan dalam televisi, khalayak dapat memahami tentang karakter dan kehidupan dari selebriti yang biasanya dikemas melalui program talkshow atau reality show (Turner, 2014). Sehingga media dapat dimanfaatkan untuk meningkatkan kepopuleran atau bahkan membuat orang biasa menjadi selebriti (Pringle, 2004).

Kepopuleran selebriti kemudian memberikan dampak pada proses referensial masyarakat atau mengikuti gaya hidup yang dilakukan selebriti di media. Bila menggarisbawahi pandangan Pringle (2004), khalayak dapat memberikan pengaruh pada gaya hidup, mode pakaian, tata rias hingga persepsi tentang kecantikan. Bila berdasar pada konsep Bandura (1963), manusia memang memiliki kodrat untuk mengimitasi perilaku orang yang dianggapnya baik. Maka proses referensial ini merupakan hal yang wajar bila dilihat dari perspektif psikologi.

Dalam praktik lanjutan, selebriti dapat menjadi komoditas untuk tujuan bisnis seperti pemasaran produk atau jasa (Pringle, 2004), termasuk pemasaran politik (Street, 2003). Berdasar pada Street (2003), selebriti memiliki "kekuatan 
lembut" dalam mempengaruhi khalayak untuk membeli produk dan jasa karena kredibilitas selebriti yang mempromosikannya. Hal ini juga berlaku dalam konteks politik, baik selebriti mendukung politisi lain (Jackson, 2018) atau selebriti mendukung dirinya sendiri dengan terjun ke dunia politik. Selebriti yang mencalonkan diri dalam pemilihan politik secara tidak langsung telah memangkas taktik komunikasi politik untuk menselebritikan kandidat dan dapat memfokuskan kampanye pada taktik lainnya.

\section{Konstruksi Figur Publik di Mata Khalayak}

Untuk menganalisis tentang pembentukan identitas personal, teori presentasi diri (selfpresentation) dapat digunakan. Teori presentasi diri yang dikemukakan oleh Erving Goffman (1959) mengkaji perilaku dan interaksi individu dalam sosial. Goffman (1956) menyatakan bahwa dalam interaksi sosial, individu dapat menerapkan sebuah performa atau aksi perihal dirinya. Secara tidak langsung, individu dapat mengonstruksi sebuah impresi tentang dirinya yang kemudian dipresentasikan kepada publiknya dalam realitas. Maka individu dapat memberikan perbedaan antara diri aslinya dengan apa yang ia presentasikan kepada publik.

Dalam realitas sehari-hari, sadar atau tidak sadar kita telah membentuk presentasi diri kita di hadapan orang lain. Biasanya seseorang ingin terlihat lebih baik dari yang sebenarnya. Istilah yang digunakan Goffman (1956: 22-24) adalah ideal. Goffman (1959) dalam konsepnya menjelaskan tentang front stage dan back stage. Menganalogikannya dengan opera sabun, front stage adalah panggung bagi para pemeran untuk berakting yang memiliki skema, alur atau naskah dialog yang telah dibuat sebelumnya. Setelah pemeran selesai berakting, pemeran pun turun dari panggung, menghapus riasannya dan melepas atribut perannya, inilah yang disebut back stage oleh Goffman (1956), sifat dan atribut dari individu yang sesungguhnya, tanpa adanya intensi untuk memberikan kesan yang baik pada orang lain.

Dengan menggunakan perspektif pemasaran, strategi personal dapat dielaborasikan secara lebih mendetail dan sesuai dengan kaidah pemasaran. Williams (2014) mengelaborasi tentang penggunaan identitas personal secara naratif dalam pengembangan taktik meningkatkan penjualan barang atau jasa. Personal branding bukanlah usaha untuk meningkatkan kemampuan, motivasi ataupun ketertarikan dari individu, namun lebih mengutamakan pada bagaimana individu "dijual" di depan khalayak (Lair, Sullivan \& Cheney 2005). Konsep personal branding telah digunakan sejak awal dekade 2000an, yang praktiknya digunakan "tak hanya oleh para figur publik yang memiliki citra yang kuat, seperti musisi atau atlet, tetapi juga orang biasa yang dapat memanfaatkan teknologi komunikasi modern sebagai usaha pemasaran" (Khamis, Ang \& Welling, 2016). Dengan penerapan personal branding yang efektif, hasrat atau ketertarikan khalayak terhadap individu akan meningkat (Cheney \& Christensen, 2001). 
Seorang selebriti ataupun figur publik tidak akan lepas dengan personal branding. Setiap figur publik perlu personal branding agar dapat membentuk ciri khas yang lebih kuat dan berbeda dengan ciri khas dari figur publik lainnya. Contohnya persona aktor internasional, Tom Cruise yang dikenal garang dan Jim Carrey yang dikenal lebih humoris. Pemanfaatan personal branding dapat meliputi konten media massa, agensi hubungan masyarakat, penggemar, fotografer, penata rambut, pelatih kebugaran, hingga dokter (Coombe 1992). Sehingga informasi yang kita dapat mengenai figur publik bisa saja merupakan hasil pembentukan personal branding, yakni front stage dari figur publik itu sendiri.

Dalam pengembangan konsep personal branding di ranah digital, penggunaan media sosial menjadi satu hal yang wajib. Personal branding melalui media sosial berperan dengan atensi dan narasi, yang kemudian berpotensi meningkatkan popularitas selebriti secara signifikan (Khamis, Ang \& Welling 2016). Personal branding melalui media sosial dibutuhkan bagi selebriti mengingat karakter khalayak yang saat ini semakin lekat dengan media baru (Khamis, Ang \& Welling 2016). Good (dalam Khamis, Ang \& Welling 2016) secara spesifik menyebutkan bahwa media sosial dapat dijadikan sebagai senjata pembentuk identitas. Fleksibelitas dalam fitur merupakan perihal yang memudahkan penggunaan media sosial sebagai mediasi diri, seperti unggahan blog dan foto yang dapat terkoneksi dengan beberapa media sosial lainnya. Hal ini pula yang membuat media sosial sangat dekat dengan konstruksi identitas (Berger dalam Khamis, Ang \& Welling 2016).

Dalam level yang lebih personal, figur publik dapat mengefektifkan penggunaan media sosial dalam penerapan personal branding. Bila berdasar pada konsepsi dari Holloway (dalam Gander 2016), personal branding berisikan tentang nilai, keahlian dan citra yang dapat dituangkan pada perilaku seperti cara berbicara, cara berpakaian, tingkat edukasi hingga kemampuan mempresentasi sesuatu. Media sosial dapat memberikan presentasi tentang aspek perilaku tersebut dengan efektif dengan fiturnya yang yang cukup lengkap, baik teks (caption atau status), audio maupun visual. Salah satu media sosial yang paling populer akhir-akhir ini yaitu Instagram, memiliki fitur yang dapat memfasilitasi perilaku dan aspek personal branding dengan mengunggah foto maupun video yang mana kategorisasinya cukup lengkap (contoh: feed, story dan IG TV).

\section{Balutan Agama dalam Pembentukan Identitas Politik Figur Publik}

Dalam menunjukkan ketertarikan pada politik, figur publik dapat menggunakan pesan secara implisit maupu eksplisit. Pakaian, cara berkomunikasi, hingga tindakannya dapat menjadi identitas politik. Identitas dalam diri seseorang dapat saja sekaligus mewakili institusi baik itu etnisitas, agama dan nasionalitas (Sukamto, 2010:13). Jika dilihat secara literal, Aksi 212 merupakan aksi politik dengan balutan agama. Cole dan Stewart (1996: 132) menyebutkan bahwa perilaku politik sangat 
berkaitan dengan identitas politik, yang didefinisikan sebagai "pola kepercayaan yang terkait dengan hubungan sosial dan struktural yang menghubungkan individu dengan kelompok sosial, (dengan) adanya relevansi ranah politik dengan pribadi." Ukuran identitas politik bagi Cole dan Stewart (1996) termasuk diantaranya adalah arti-penting politik, orientasi kolektif, kesalahan sistem, ideologi, dan ketidakpuasan kekuasaan.

Identitas politik dan politik identitas adalah dua kajian yang berbeda. Gentry (2018) memfokuskan identitas politik pada individu dan internalisasi diri, yakni bagaimana individu menciptakan pemahaman mereka tentang diri mereka sendiri. Sedangkan politik identitas berakar pada adaptasi identitas dari ilmu politik yang memperhitungkan struktur kekuasaan, dinamika kelompok, dan konstruksi sosial. Politik identitas merupakan bagian dalam memahami sebuah kelompok yang identitasnya secara sosial dibangun dan terpinggirkan. Politik identitas berfokus pada aspek eksternal dan sosial dari identitas, sedangkan identitas politik merupakan internalisasi individu.

Identitas politik secara kritis adalah sesuatu yang sengaja dibuat dan secara ontologis (Martha, 1996). Terdapat dua elemen dasar dari identitas politik yaitu pembentukan identitas sebagai proses dan identitas sebagai status (Gentry, 2018). Identitas sebagai proses dilalui ketika individu memperoleh kepercayaan, preferensi, identifikasi diri mereka sebagai orang-orang politik (Gentry, 2018). Selama proses pembentukan identitas politik, individu mengalami tahap difusi, yakni perubahan atau penggantian ke identitas baru
(Khamdan \& Wiharyani, 2018, 210). Dalam konteks ini, figur publik yang semula berada di lingkungan hiburan melalui tahapan proses difusi ke identitas politik.

Secara perilaku, seseorang yang memiliki identitas dapat menunjukkan pada orang lain tentang komitmennya pada keyakinan dan nilai-nilai tertentu. Sementara identitas dapat memandu fokus, tindakan dan kejelasan individu. Individu pun dapat membangun identitas dari cara berperilaku dan umpan balik perilaku tersebut. Sehingga konstruksi identitas akan melihat sisi praktis individu (Schwartz, 2001).

\section{Metode Penelitian}

Penelitian ini merupakan penelitian kualitatif dengan pendekatan kritis. Penelitian bertujuan untuk menggali makna-makna yang ada dalam media sehingga tergolong pada penelitian kualitatif. Hasil penelitian berupa data deskriptif mengenai wacana branding dan politik. Penelitian memiliki tahapan pengumpulan data dan analisis data dengan perspektif dan mendeskripsikan dalam hasil.

Metode yang digunakan dalam penelitian ini adalah analisis konten wacana dengan pendekatan kritis. Bila mengacu pada Krippendorff (2004), analisis konten wacana adalah penelitian untuk membuat kesimpulan dan pandangan valid yang berasal dari teks atau objek lainnya yang bermakna dengan tujuan pendekatan konteks. Analisis wacana pada dasarnya berfungsi untuk melihat perilaku verbal 
dari manusia, baik simbolis hingga keberlangsungan event atau kejadian yang berkaitan dengan proses komunikasi (Lasswell, Lerner \& Pool dalam Macnamara, 2005). Metode ini sangat cocok dengan latar belakang penelitian ini yang bermaksud untuk memberikan pandangan dan perluasan makna dari konten yang ada di media.

Analisis wacana kritis secara garis besar dilakukan dengan 4 tahapan analisis (Fairclough, 2001; Fairclough, 2010). Pertama adalah fokus penyimpangan atau ketidakbenaran sosial yang tersirat secara semiotika. Kedua, mengidentifikasi hambatan dan halangan yang ada dalam mengatasi kesalahan sosial dan mengapa kesalahan tersebut terjadi dengan analsis jaringan, relasi dan wacana. Ketiga adalah dengan melihat faktor apa yang membuat kesalahan tersebut dibutuhkan dalam sosial. Dan keempat adalah dengan mengidentifikasi solusi atau cara untuk melewati hambatan tersebut. Dalam penelitian ini, branding agama dalam pembentukan identitas politik dari selebriti menjadi kesalahan sosial yang diangkat.

Perkembangan analisis wacana dewasa ini membuatnya tidak lagi hanya berfokus pada konten dalam bentuk teks. Penelitian ini mengembangkan konsep multimodal, yakni dengan mempertimbangkan teks, visual dan penempatan. Pertimbangan multimodal dalam analisis wacana telah dikemukankan oleh Kress dan van Leeuwen serta Gibbons (dalam Wang, 2014) tentang fleksibilitas dari metode analisis wacana (critical discourse analysis) dengan perluasan konteks dari beragam sumber dan konstruksi modal lainnya. Menekankan pada branding dan politik, penelitian ini mempertimbangkan aspek teks, visual dan konteks di media sosial yang dapat menjadi sumber analisis. Metode ini digunakan mengingat perkembangan media yang telah menggunakan beragam aspek multimedia.

Sebelum mengumpulkan data, dilakukan pemilihan konten dengan cara purposif yang difokuskan untuk melihat dan memberikan fokus dan kedalaman analisis data pada hasil. Beberapa batasan dalam pemilihan konten dan profil selebriti adalah pada keikutsertaannya dalam Aksi 212 atau rangkaiannya, yang ditandai dengan unggahan feed di sosial media Instagram atau yang berkaitan dengan Aksi 212 dan keaktifannya di dunia politik, baik keaggotaannya pada mereka dalam partai politik atau menjadi kandidita dalam pemilihan umum. Unggahan selebriti pada hari terjadinya Aksi (baik Aksi 212 maupun rangkaiannya) tersebut dijadikan sebagai data dasar teks yang akan dianalisis dalam penelitian ini. Beberapa teks lainnya adalah teks pendukung wacana yang beririsan dengan konteks pembentukan identitas, politik dan agama.

Walaupun selebriti yang mengikuti Aksi 212 dan aktif di bidang politik terdapat lebih dari lima, tetapi hanya didapat dua selebriti yang memenuhi kualifikasi dengan mengunggah atau masih memiliki unggahan di feed Instagram, Fauzi Baadilla dan Rachel Maryam. Instagram dipilih dikarenakan fiturnya yang mendukung wacana multimodal. Selain menjadi tokoh utama dalam film 212: The Power of Love dan aktif di kegiatan Aksi 212, Fauzi Baadilla juga berkecimpung dalam 
dunia politik dengan tergabung dalam kader partai dan pernah ikut sebagai calon pemilihan umum. Sedangkan Rachel Maryam belakangan secara eksplisit beralih dari selebriti menjadi politisi. Dari dua selebriti tersebut, selain unggahan pada hari Aksi 212, dipilih konten yang representatif dengan konteks branding, politik dan Aksi 212 sebagai data pendukung.

\section{Temuan \& Pembahasan}

Penyimpangan sosial: pendekatan agama dalam membentuk identitas politik selebriti

Agama menjadi satu pendekatan yang digunakan oleh figur publik dalam membangun identitas politik yang agamis. Figur publik seperti Fauzi Baadilla dan Rachel Maryam tidak ketinggalan untuk unjuk suara maupun unjuk aksi dalam Aksi 212. Keterlibatan para figur publik pada Aksi 212 menjadi panggung dalam proses pembentukan identitas politik individu. Munculnya para figur publik ini menunjukkan terjadinya internalisasi identitas yang awalnya mencitrakan dirinya pada dunia hiburan kemudian melebur dengan atribut pakaian lebih agamis, ucapan yang dekat dari ayat Al Qur'an, hingga keikutsertaannya pada gerakan Islam.

Sayangnya, branding agama yang digunakan oleh selebriti politik untuk melakukan pendekatan dengan tujuan mendapatkan suara politik. Penggemar selebriti yang notabene telah mengenal beberapa sifat dan karakter personal dari selebriti idolanya tersebut berpotensi besar menjadi pendukung. Dalam konteks pemasaran politik, hal ini menjadi krusial dimana pemilih akan cenderung memilih dengan pertimbangan kredibilitas (Street, 2003), sehingga selebriti lebih diuntungkan. Selain itu, kepercayaan masyarakat secara umum tentang seorang yang taat beragama dicitrakan individu yang berperilaku lebih baik sepertinya masih tetap berlaku. Bila menggunakan sudut pandang self-presentation dari Goffman (1959), bisa saja selebriti yang mencalonkan diri di pemilu mengikuti serangkaian kegiatan agama ataupun terlihat taat beragama dengan menggunakan objek pendukung dengan tujuan dianggap baik oleh khalayak.

Pendekatan agama sebagai bagian dari pemasaran politik bukanlah cerminan yang tepat untuk dilakukan. Pasalnya, pemilu atau kegiatan politik lainnya bukanlah perlombaan pemahaman atau praktik agama, namun tentang bagaimana menjalankan amanat masyarakat untuk mengembangkan negara atau daerah menjadi lebih baik. Pekerjaan kepala daerah atau wakil rakyat merupakan pekerjaan yang mementingkan keahlian seperti pengendalian rakyat, menentukan keputusan, administrasi atau tata kota, yang hampir semuanya tidak berkaitan dengan agama. Maka konteks perpolitikan tidak memiliki banyak korelasi dengan urusan agama seperti pendekatan yang dilakukan oleh beberapa politisi.

Faktor dan alasan pendekatan agama dalam membentuk identitas politik selebriti

Melihat keterkaitannya antara Aksi 212 dengan agama Islam, banyak yang akhirnya memanfaatkan aksi tersebut sebagai media 
perantara dan pendukung identitas. Dalam praktik politik, Aksi 212 memiliki kekuatan besar dalam membentuk ataupun menggiring perspektif politik masyarakat. Waktu penyelenggaraan Aksi 212 sangat dekat dengan waktu pemilihan gubernur Provinsi DKI Jakarta yang dilaksanakan pada awal tahun 2017. Tujuan massa yang ingin menggulingkan Ahok menandakan besaran pemilih yang kontra dengan Ahok yang saat itu mencalonkan diri kembali sebagai gubernur. Aksi ini pun kemudian berbuntut pada Pemilu Presiden (dan Anggota DPR dan DPD) tahun 2019 yang mencalonkan Prabowo Subianto, Ketua Umum Partai Gerindra. Sehingga Aksi 212 dan serangkaiannya sangat lekat dengan kubu Partai Gerindra. Selebriti dari Partai Gerindra yang menyadari akan hal ini ikut mewarnai Aksi 212 untuk kesempatan meraih popularitas dan simpati dari peserta aksi atau masyarakat yang pro dengan aksi.

Aksi 212 dapat menjadi elevator bagi selebriti yang terjun pada ajang politik. Pola pendekatan Aksi 212 dalam dapat dikatakan cukup 'lembut' karena menggunakan kedok keagamaan, yakni dengan sebutan Aksi Bela Islam. Selebriti dapat memanfaatkan aksi ini untuk menghaluskan perpindahan karir dari artis menjadi politikus yang biasanya kerap menuai kritik dan cibiran (Rantung, 2019; Nadhiroh, 2019). Maka bila dilihat secara kritis, Aksi 212 hanya sebuah alat untuk melancarkan urusan perpolitikan bagi selebriti.

Wacana dalam konteks agama dan politik selebriti secara semiotik

Dalam melakukan pendekatan keagamaan personal, selebriti dapat memanfaatkan media sosial pribadi untuk menyampaikan pesan sekaligus untuk melakukan self-branding. Fauzi Baadilla dan Rachel Maryam terbukti meggunakan sosial media yang mereka miliki untuk menunjukkan keikutsertaannya dalam aksi pun juga kecenderungan politiknya. Secara garis besar, keduanya menunjukkan keikutsertaan dan kecenderungan politik yang selaras dengan Aksi 212.

Penggunaan unsur keislaman juga tersirat pada akun Instagram Fauzi Baadilla. Selebriti yang juga peserta Aksi 212 ini (Aragon 2018), selain melakukan personal branding dengan kontenkonten foto dengan tema Islam dan politik. Kolom bio atau keterangan akunnya pun digunakan untuk memberikan kesan yang Islami (Gambar 1). Fauzi menuliskan "Al-Kahfi: 39," dan "hadza min fadhli robbi," yang artinya "Ini semua adalah berkat anugerah Tuhanku." Kalimat ini diilhami oleh kisah Nabi Sulaiman AS dengan segala kekayaannya. Isian ini memberikan kesan keislaman yang cukup terepresentasi dan dapat tertanam di benak khalayak.
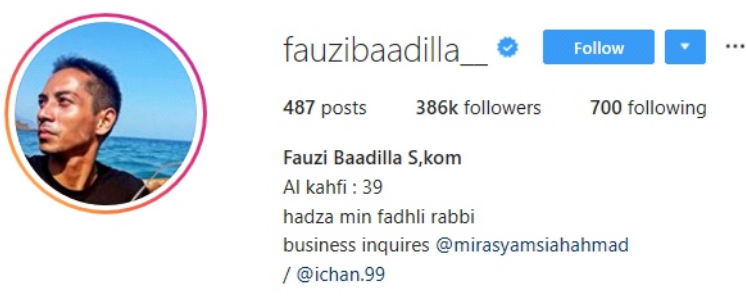

Gambar 1

Tampilan utama akun Instagram Fauzi Baadilla (Sumber: Akun Instagram @fauzibaadilla_)

Menuliskan syair kegamaan tentunya memberikan indikasi tentang kerohanian pribadi 
tersebut, karena fungsi kolom tersebut pada Instagram bertujuan untuk menunjukkan deskripsi biodata diri yang dianggap representatif bagi akun atau pribadi akun tersebut.

Sedangkan isian data diri Rachel Maryam di Instagram menunjukkan representasi hasrat politik yang sangat jelas. Rachel menggunakan foto dengan konsep studio yang menggunakan pakaian formal berhijab. Di belakangnya tampak bendera merah putih dan bendera Gerindra. Foto ini merepresentasikan statusnya sebagai seorang muslim dan partipasinya dalam partai politik. Tentu saja bendera merah putih sebagai simbol nasionalisme.

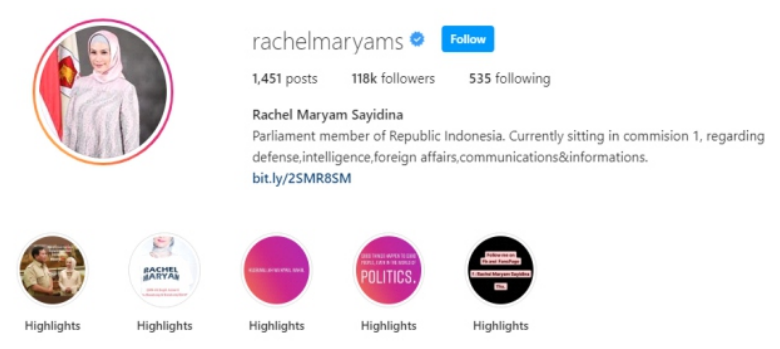

Gambar 2

Profil Instagram Rachel Maryam

(Sumber: Akun Instagram @rachelmaryams diakses 16 Desember 2019)

Bio instagram Rachel tertulis "Parliament member of Republic Indonesia. Currently sitting in commission 1, regarding defense, intelligence, foreign affairs, communications \& information." yang artinya "Anggota Parlemen Republik Indonesia. Saat ini duduk di Komisi I, yang berhubungan dengan pertahanan, intelijen, urusan luar negeri, komunikasi \& informasi" (Gambar 2). Rachel Maryam menunjukkan posisinya saat ini yang telah duduk pada kursi parlemen dengan minat politiknya yang ia presentasikan baik di konten highlight ataupun pada setiap unggahan foto maupun videonya.

Fauzi Baadilla juga memanfaatkan unggahan feed di Instagram dalam membentuk citra keislaman dan politik.

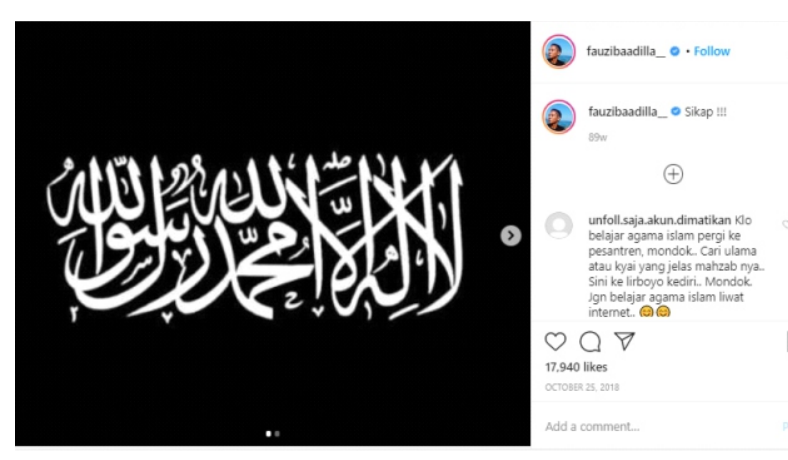

Gambar 3

Unggahan Fauzi Baadilla

(Sumber: Akun Instagram @ fauzibaadilla diakses 16 Desember 2019 terarsip di: https://www.instagram.com/p/BpWSVknnEQa/)

Pada salah satu unggahan, Fauzi mengunggah gambar bendera hitam jihad dan potongan berita tentang pernyataannya terhadap kasus pembakaran bendera tauhid pada gambar kedua unggahan dengan caption bertuliskan "Sikap !!!" (Gambar 3). Gambar tersebut bertuliskan kalimat syahadat dengan gaya kaligrafi berwarna putih dengan latar berwarna hitam. Gambar ini dikenal dengan sebutan bendera tauhid dan juga "bendera hitam jihad" yang sering digunakan oleh kelompok jihad Islam dalam menyuarakan perlawanan. Dalam konteks ini, Fauzi Baadilla menggunakan gambar tersebut untuk menyatakan sikapnya dalam menanggapi kasus pembakaran bendera tauhid yang menginginkan pelaku untuk dihukum. Hal lain yang perlu diperhatikan adalah waktu diunggahnya konten, yakni akhir tahun 2018, ketika suasana 
perpolitikan sedang panas menjelang pemilihan presiden 2019. Identitas agama menjadi salah satu balutan yang melekat dalam kampanya pemilu presiden 2019. Beberapa kelompok muslim, diantaranya bersinggungan dengan peserta 212 , menyatakan dukunganya pada kubu calon presiden Prabowo Subianto.

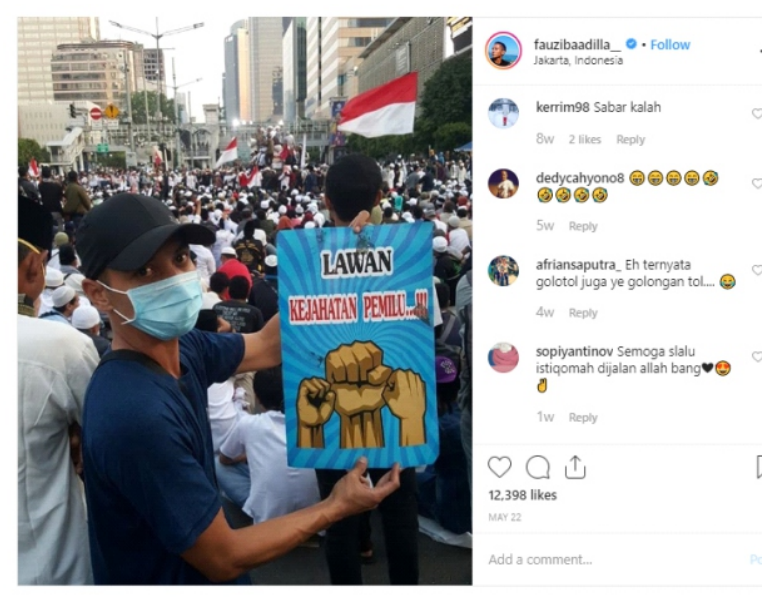

Gambar 4

Fauzi Baadilla dalam aksi tanggal 22 Mai 2019.

(Sumber: Akun Instagram @fauzibaadilla diakses 16 Desember 2019 terarsip di: https://www.instagram.com/p/Bxw33EKhpDF/)

Rajut antara Islam dengan kubu politik calon presiden Prabowo Subianto yang dilakukan Fauzi semakin rekat dengan unggahannya pada $22 \mathrm{Mei}$ 2019 (Gambar 4). Hari itu terjadi sebuah aksi

yang memprotes keputusan Bawaslu yang memenangkan Calon Presiden Joko Widodo dalam Pemilu Presiden 2019. Aksi yang merupakan bagian dari rangkaian Aksi 212 ini memang diawali oleh aksi damai yang dilakukan pada 21 Mei 2019 yang berakhir ricuh akibat provokasi. Melihat dari gambar yang diunggah Fauzi, terlihat dirinya, yang sedang mengikuti aksi, membentangkan sebuah poster yang bertuliskan “lawan kejahatan pemilu...!!”. Di latar belakang gambar terlihat banyak peserta aksi yang sedang duduk, mayoritas menggunakan pakaian putih dan beberapa diantaranya menggunakan peci, pakaian simbolis dalam agama Islam. Aksi ini dilakukan dengan atas nama Islam namun dengan tujuan politik, yakni memprotes hasil pemilu. Dengan keikutsertaannya dalam aksi ini, Fauzi melekatkan dirinya dengan 2 identitas, Islam dan politik.

Keterlibatan Rachel Maryam dalam Aksi 212 terlihat dalam video unggahan di media sosial Instagram pribadinya pada 5 Desember 2016 (Gambar 5). Dalam video ini Rachel Maryam bersama beberapa rekannya memperlihatkan situasi di lapangan Monas yang ramai. Video ini kemudian diberi caption, "Kami bangga menjadi bagian dari sejarah. Sejarah dimana jutaan umat muslim berkumpul karena panggilan iman, iman kepada Al-Quran \#kamialumni212 \#aksibelaislam \#belaislamjilid3 \#latepost". Dari caption tersebut seakan-akan menekankan bahwa aksi 212 merupakan bagian dari iman kepada Al Quran. Nuansa Islam dan politik tidak dapat luntur pada setiap presentasi diri dari seorang Rachel Maryam. Ide dan nilai yang ia yakini terus direproduksi melalui media sehingga mampu menyematkan pada khalayak pengikutnya tentang identitasnya. 


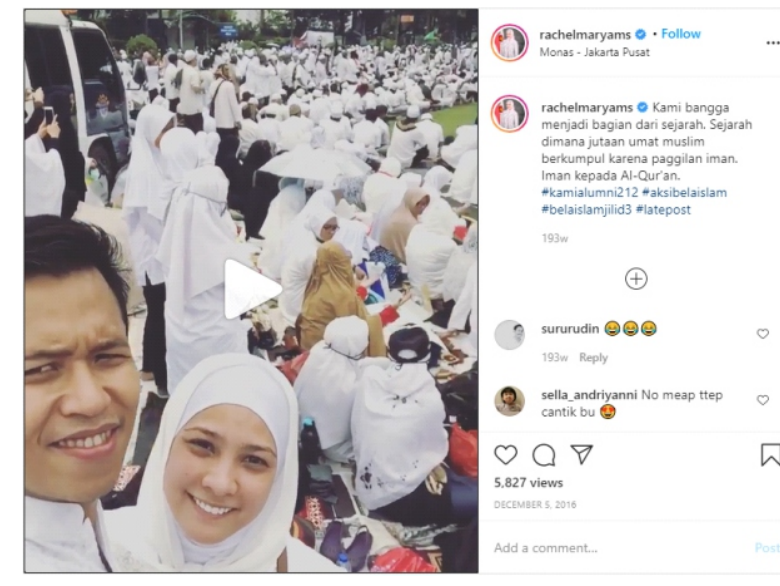

Gambar 5

Rachel Maryam dalam aksi tanggal 2 Desember 2016. (Sumber: Akun Instagram @rachelmaryams diakses 16 Desember 2019 terarsip di https://www.instagram.com/p/BNofft4DX75/)

Rachel juga terlihat mengikuti aksi rangkaian dari Aksi 212 dalam foto yang diunggah pada 22 Mei 2019 ini (Gambar 6). Berdasarkan peristiwa waktu unggah Rachel, aksi tersebut merupakan aksi rangkaian dari Aksi 212 yang merupakan penolakan terhadap rekapitulasi hasil perhitungan suara Pemilu Presiden tahun 2019. Pemilu Presiden 2019 saat itu menuai kegaduhan dikarenakan kasus ratusan petugas KPPS. Kasus ini kemudian dikritisi oleh kelompok pendukung Capres Prabowo-Sandi yang menganggap pemerintah tidak bertanggungjawab atas meninggalnya petugas-petugas KPPS tersebut. Dari caption Rachel Maryam tersebut seakan-akan Rachel memperlihatkan kontribusi dan perannya untuk menuntut investigasi kematian 600 petugas pemilu. Unggahan itu diperkuat dengan fotonya yang bersama dokter-dokter spesialis. Disini dapat terlihat bahwa penggunaan sosok pakar dianggap kredibel dalam menyampaikan pesan. Foto ini menggunakan tagar \#aksidamai dimana tagar ini diinisiasi oleh gerakan Aksi 212, merujuk pada peristiwa 4 November 2016 mengenai demonstran muslim yang memprotes pernyataan Basuki Tjahaja Purnama yang dianggap menistakan Surat Al Ma'idah.

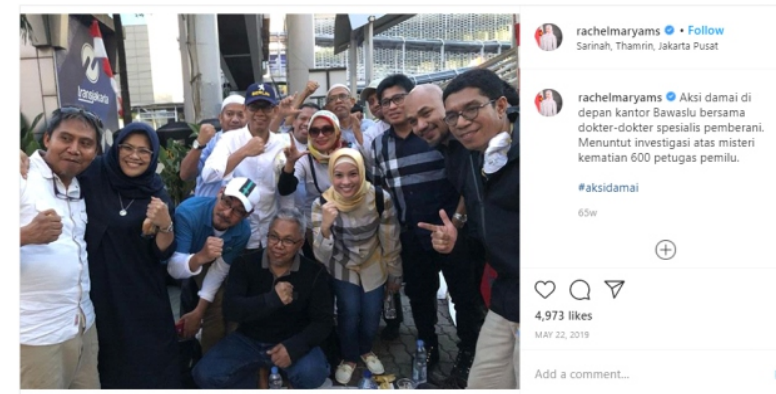

Gambar 6

Rachel Maryam dalam aksi tanggal 22 Mei 2019. (Sumber: Akun Instagram @rachelmaryams diakses 16 Desember 2019 terarsip di https://www.instagram.com/p/Bxw-OODH6SE/

Urgensi pendekatan agama dalam pembentukan identitas politik selebriti

Keiikutsertaan Fauzi Baadilla dan Rachel Maryam dalam rangkaian Aksi 212 dan aksi-aksi selanjutnya menunjukkan sebagai muslim yang politis. Mengingat keartiasannya, mereka dapat memanfaatkan pengikut dan fansnya untuk dijadikan kekuatan politik. Walaupun dirinya tidak terpilih, Fauzi sendiri merupakan kader dari Partai Gerindra, yang mencalonkan diri dalam pemilihan calon legislatif di Dapil Jawa Barat VI pada tahun 2019 (Septianto, 2019). Sedangkan Rachel Maryam berhasil menduduki kursi jabatan di DPR RI (Farisa, 2019). Bila dibandingkan dengan Fauzi, Rachel lebih terbuka memanfaatkan media sosialnya untuk agenda kampanye politik, sedangkan Fauzi tidak memanfaatkan sosial medianya secara gamblang. Keterlibatan Fauzi 
Baadilla dan Rachel Maryam dalam aksi Islam dan pencitraannya dalam media sosial merupakan agenda mereka untuk mendapatkan pendukung dalam karir politiknya.

Ada beragam hal yang mempengaruhi alasan dan intensi dari selebriti dalam terjun ke dunia politik. Alasan yang biasanya diangkat oleh selebriti adalah keinginan atau niat dalam membangun negeri. Jika citra personal selebriti tersebut baik di mata khalayak, perpindahan ke dunia politik dengan alasan ini akan dilihat sebagai niat baik dari selebriti tersebut dan menjadi modal besar baginya. Alasan lain yang tersirat adalah perpindahan karir. Turunnya pamor sebagai artis atau pekerjaan lainnya di dunia entertainment dapat memaksa selebriti untuk berpindah ke karir lainnya, termasuk politisi. Membanting stir menjadi politisi tentunnya akan menguntungkan mengingat selebriti telah memiliki popularitas sehingga dapat memulai karir dengan tidak dari 0 .

Disamping faktor-faktor dari perspektif aktor, khalayak Indonesia sendiri masih terbilang latah dalam mengonsumsi konten di media sosial. Tidak hanya dalam konteks politik, netizen Indonesia masih belum mencerna informasi-informasi dengan baik. Bila melihat kondisi digital literasi di Indonesia, belum banyak kegiatan peningkatan literasi digital dalam lingkup masyarakat (Kurnia \& Astuti, 2017). Kondisi ini memberikan keuntungan bagi pelaku kampanye politik untuk melakukan penggiringan opini.
Menanggulangi permasalahan sosial agama dan politik pada selebriti

Menangani fenomena pembentukan identitas politik yang dilakukan oleh selebriti, harapan positif perlu diluapkan dari sisi aktor maupun khalayak. Pertama yang perlu dioptimalisasikan adalah dari sisi khalayak. Sebagai calon pemilih khalayak perlu lebih bijak dalam mengonsumsi informasi politik. Keahlian-keahlian yang mendukung dalam bidang politik, seperti kepemimpinan, administrasi dan manajemen pemerintah, perlu menjadi pertimbangan utama bagi calon pemilih, bukan popularitas. Hal ini perlu didukung dengan peningkatan kualitas digital literasi masyarakat. Sehingga pemilih dapat memilih dengan lebih cerdas dan objektif.

Aktor politik juga perlu meningkatkan kualitas aspek-aspek pendukung dalam kampanye. Kurang pas rasanya jika peran politik yang membutuhkan keahlian politik, dikampanyekan tidak sesuai dengan keahlian politik. Pendekatan agama seperti yang dilakukan Fauzi Baadilla dan Rachel Maryam dalam beragenda politik mungkin merupakan taktik yang baik untuk mengambil hati pemilih, namun tidak berkorelasi dengan fungsi kerja sebagai politisi. Kesalahan ini seperti telah menjadi lumrah dan diikuti oleh politisi lainnya, sehingga banyak kampanye yang mengutamakan pamor dan popularitas. Spanduk-spanduk kampenye pemilihan kepala daerah hanya menampilkan wajah dan slogan sebagai pesan utama, bukan visi misi dan programnya. Kebiasaan ini sebaiknya diperbaiki seiring dengan tingkat edukasi serta literasi digital politik masyarakat. 


\section{Kesimpulan}

Aksi 212 adalah pertanda bahwa aspek agama dan politik memiliki irisan sangat dalam. Yang menarik, selebriti pun ikut mewarnai aksi tersebut layaknya memiliki keluh kesah yang sama dengan para peserta Aksi 212 lainnya. Namun keikutsertaan para figur publik tersebut sarat akan kepentingan politik. Melihat banyaknya figur publik yang terjun ke dunia politik, keikutsertaan pada Aksi 212 bisa jadi hanya sebagai penambahan nilai identitas agama mereka. Kemungkinan tersebut cukup signifikan melihat karakter masyarakat Indonesia kini cenderung menekankan pada nilai keagamaan, terutama Islam. Perkara identitas diri, agama, politik dan citra personal selebriti menjadi semakin rancu.

Momen aksi 212 digunakan sebagai panggung oleh Fauzi Baadila dan Rachel Maryam untuk menunjukkan pada masyarakat tentang identitasnya sebagai seorang muslim yang berperan dalam membela Islam. Narasi yang diciptakan oleh selebriti ini tidak cukup sampai pada perilaku keislamannya, namun meliputi juga tanda-tanda dalam unggahan di media sosial Instagram. Repreentasi atribut dan narasi agama memiliki kekuatan dalam mendorong empati masyarakat ke dalam agenda politik. Cara tersebut menjadi salah satu upaya branding selebriti untuk menjaring pengikut agar memiliki suara yang sama dalam konteks politik.

Akhirnya personal branding yang diciptakan membentuk identitas baru. Difusi identitas terjadi, dari identitas sebagai selebriti menjadi identitas sebagai politikus yang agamis. Agama menjadi balutan performa dalam pendekatan politik. Kekaguman khalayak terhadap selebriti dikorbankan atas nama politik. Tahta atas kuasa politik adalah pelaku yang mengubah kehidupan sosial hubungan selebriti-penggemar menjadi penguasa-rakyat.

Riset ini berkontribusi dalam kajian personal branding, bahwa pembentukan identitas secara pribadi melalui media merupakan upaya yang efisien tidak hanya sebagai aktualisasi diri semata melainkan mampu mempengaruhi khalayak untuk dapat mengambil keputusan yang sejalan dengan nilai yang dibangunnya. Di era digital ini, selebriti mampu menciptakan citranya sendiri sesuai keinginan dan kebutuhannya dengan menggunakan atribut yang dapat diterima oleh mayoritas masyarakat. Agama bukan semata sebagai nilai moral yang dapat diukur oleh tingkat keimanan, agama pun dapat menjadi tameng atas kepentingan tertentu. Dari kajian inilah dapat dirumuskan adanya penciptaan branding oleh selebriti merupakan serangkaian agenda politik dalam kasus ini adalah bentuk pemasaran politik melalui perilaku positif selebriti.

Riset ini memiliki keterbatasan pada ruang lingkup media sosial Instagram. Interpretasi hanya dilakukan pada beberapa unggahan Instagram pribadi milik selebriti yang terlibat dalam Aksi 212, tidak seluruh unggahan yang berbau politik atau agama, pun tidak mencakup unggahan dari platform lainnya. Maka riset mendatang dapat mengeksplor upaya branding selebriti yang dapat dibandingkan antar platform media dan dapat pula menganalisis interpretasi khalayak khususnya pengikutnya terhadap branding selebriti Islam yang berpolitik. 


\section{REFERENSI}

Aragon, H. H. 5 Desember 2018. “Hijrah, 180 seleb kondang ini ternyta satu komunitas pengajian."Brilio.net. https://www.brilio.net/selebritis/hijrah18-seleb-kondang-ini-ternyata-satukomunitas-pengajian-180305t.html.

Arfiyani, W. 2 Desember 2018. "Para tokoh politik ini tampak mengenakan pakaian serba putih seperti peserta reuni lainnya." Brilio.net. https://www.brilio.net/sosok/10-tokoh-politik-ini-hadiri-reuni-212-adayang-orasi-181202d.html.

Bandura, A. (1963). The role of imitation in personality development. Dimensions of psychology, 16, 121-153.

Bandura, A. (1986). Social Foundations of Thought and Action: A Social Cognitive Theory. New Jersey: Prentice-Hall, Inc.

Cheney, G. \& Christensen, L. T. (2001). Organizational identity: Linkages Between Internal and External Communication. Fredric M. Jablin \& Linda L. Putnam (Eds.). The New Handbook of Organizational Communication : Advances in Theory, Research, and Methods. California: Sage Publications. 231-269.

CNN Indonesia. 1 Desember 2018. "Aksi 212, dari Mulut Ahok ke Reuni Aroma Pilpres." https://www.cnnindonesia.com/nasional /20181201121150-20-350369/aksi-212dari-mulut-ahok-ke-reuni-aroma-pilpres.
Cole, E. \& Stewart, A. (2015). Meanings of Political Participation Among Black and White Women: Political Identity and Social Responsibility. Journal of Personality and Social Psychology, 71(I). 130-140. DOI: https://doi.org/10.1037/00223514.71.1.130.

Coombe, R. J. (1992). The celebrity image and cultural identity: Publicity rights and the subaltern politics of gender. Discourse, 14(3), 59-88.

Darmawan, I. (2015). Keterlibatan selebriti dalam pemilu Indonesia pasca orde baru. Sosiohumaniora, 18(3), 236-242.

Dewan Pers. 29 Mei 2009. “Caleg Selebritis dan Jurnalis." Publikasi Dewan Pers. https://dewanpers.or.id/publikasi/opini_ detail/17/Caleg_Selebritis_dan_Jurnalis/.

Fairclough, N. (2001). Critical discourse analysis as a method in social scientifc research. Wodak, R. \& Meyer, M. (Eds.). Methods of Critical Discourse Analysis. (pp.121-136). London: Sage Publication.

Fairclough, N. (2010). Critical Discourse Analysis: The Critical Study of Language ( $2^{\text {nd }}$ Edition). New York: Routledge.

Farisa, F. C. 31 Agustus 2019. "13 Selebriti Melenggang ke DPR, Tak Ada Mulan Jameela." Berita Kompas Daring. https://nasional.kompas.com/read/2019/ $08 / 31 / 14504521 / 13$-selebritimelenggang-ke-dpr-tak-ada-mulan- 
jameela/.

Finnemore, M. (1996). National Interests in International Society. New York: Cornell University Press.

Gander, M. (2016). Managing your personal brand. Perspectives: Policy and Practice in Higher Education, 18(3), 99-102. DOI: https://doi.org/10.1080/13603108.2014. 913538.

Gentry, B. (2018). Why Youth Vote: Identity, Inspirational Leaders, and Independence. Bridgewater: Springer International Publishing.

Gerintya, S. 26 Juli 2018. "Hanya 16 Persen Caleg Selebriti yang Lolos Pemilu 2014." Laporan Tirto.id. https://tirto.id/hanya-16-persencaleg-selebriti-yang-lolos-pemilu-2014cPVe/.

Goffman, E. (1956). The Presentation of Self in Everyday Life. Edinburgh: University of Edinburgh.

Iqbal, A. M. (2014). Internet, Identity and Islamic Movements: The Case of Salafism in Indonesia. Islamika Indonesiana 1(1), 81105 .

D O I : https://doi.org/10.15575/isin.v1i1.42/.

Jackson, D. J. (2018): The Effects of Celebrity Endorsements of Ideas and Presidential Candidates, Journal of Political Marketing, 0 . 1 - 21 . D O I : $10.1080 / 15377857.2018 .1501530 /$.
Khamdan, M. \& Wiharyani. (2018). Mobilisasi Politik Identitas dan Kontestasi Gerakan Fundamentalisme. Al-Tahrir, 18(1), 193218.

Khamis, S., L. Ang \& Welling, R. (2016). Selfbranding, 'micro-celebrity' and the rise of Social Media Influencers. Celebrity Studies. DOI: https://doi.org/10.1080/19392397.2016. 1218292.

Kurnia, N. \& Astuti, S. I. (2017) Peta Gerakan Literasi Digital di Indonesia: Studi tentang Pelaku, Ragam Kegiatan, Kelompok Sasaran dan Mitra. INFORMASI Kajian IImu Komunikasi, 47(2). Pp.149-166. https://doi.org/10.21831/informasi.v47i2 .16079 .

Krippendorff, K. (1980). Content analysis: An introduction to its methodology. Beverly Hills: Sage Publications.

Larasati, D. L. 12 November 2018. "Deretan Selebriti Dunia yang Terjun ke Politik." Detikhot. https://hot.detik.com/celeb/d4298840/deretan-selebriti-dunia-yangterjun-ke-politik/.

Macnamara, J. R. (2005). Media content analysis: Its uses, benefits and best practice methodology. Asia Pacific Public Relations Journal, 6(1), 1.

Nadhiroh, R. 30 Januari 2019. “Dicibir Cuma Bisa Duduk Manis Jika Terpilih Jadi Anggota DPR, Kirana Larasati Beri Tanggapan." 
Berita daring Tribun.

Pringle, H. (2004). Celebrity Sells. Chichester, West Sussex, England: J. Wiley.

Rantung, R. C. 19 September 2019. "Diremehkan Sebagai Anggota Dewan, Begini Kata Tina Toon." Berita daring Suara.com. https://www.suara.com/entertainment/2 019/09/19/214022/diremehkan-sebagaianggota-dewan-begini-kata-tina-toon/.

Rojek, C. (2012). Fame attack: The inflation of celebrity and its consequences. London: Bloomsbury Academic.

Schwartz, S. J. (2001). The evolution of Eriksonian and neo-Eriksonian identity theory and research: A review and integration. Identity: An International Journal of Theory and Research, 1, 7-58. https://doi.org/10.1207/S1532706XSCH WARTZ

Septiano, B. 16 Mei 2019. “Deretan Caleg Selebriti dari Dapil Jabar yang Berpotensi Gagal ke DPR", Tirto.id https://tirto.id/deretancaleg-selebriti-dari-dapil-jabar-yangberpotensi-gagal-ke-dpr-dKTk/

Siddiq, T. 2 Desember 2018. "Rizieq Ajak Reuni 212 \#2019GantiPresiden, Fadli Zon: Itu A spirasi" Te m po.co. https://nasional.tempo.co/read/1151568 / r i z i e q-a ja k - re u n i - 212 2019gantipresiden-fadli-zon-itu-aspirasi.
Style and Popular Culture. Corner, J. \& Pels, D (Eds.). Media and the restyling of politics: consumerism, celebrity, cynicism. (pp. 85-98). London: Sage Publication.

Sukamto. (2010). Politik Identitas (Suatu Kajian Awal dalam Kerangka dan interaksi "Lokalitas dan Globalisasi"). Jurnal Sejarah dan Budaya Universitas Malang 2.

Turner, G. (2014). Understanding Celebrity. London: Sage Publication.

Wang, J. (2014) Criticising images: critical discourse analysis of visual semiosis in picture news, Critical Arts. South-North Cultural and Media Studies, 28(2). 264286. D O I : $10.1080 / 02560046.2014 .906344$

Williams, B. B. (2014). Personal brand \& the branding process: From hype to actual benefits for human resources and talent management leaders. Doctoral dissertation. University of Pennsylvania. ProQuest Dissertations \& Theses Global. AAI3635765.

Street, J. (2003). The Celebrity Politician: Political 